\&.Edu.\&Sci. , The first conference on Biology, (September-2007)

\title{
Isolation and Identification of Legionella pneumophila From Different Sources
}

\author{
Amera M. M. Al-Rawi \\ College of Science \\ University of Mosel
}

\author{
Khadija Kh. Mustafa \\ College of Science Education \\ University of Sallahddin
}

\section{الخلاصة}

تضنت الدر اسة عزل وتسشخيص جرثومسـة Legionella pneumophila مسن قشع المرضى الو افدين في مستشفى كوماري ورزكاري باجناس و اعمار مختلفة فـي مدينــة

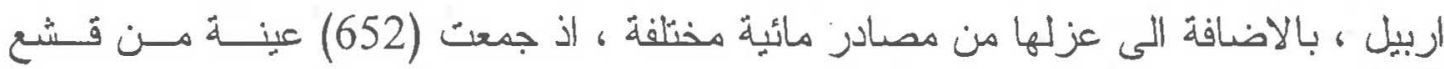
المرضى و (100 ) عبنة من مياه حنفية وشور ات الاستحمام و (72 ) عبنة من بر ادات المياه.

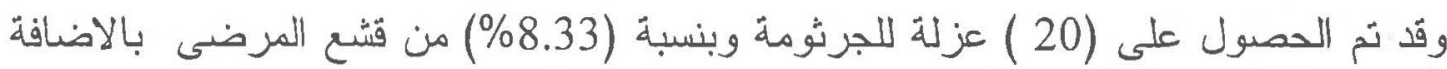

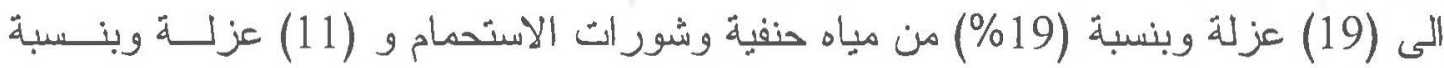
(15.27) من بر ادات المياه.

تم تشخيص عز لات الجرثومة اعتمادا على الصفات الشكلية و المزر عية و الكيموحيوية

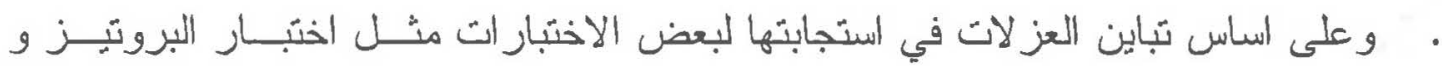
DNase (Biotyping)

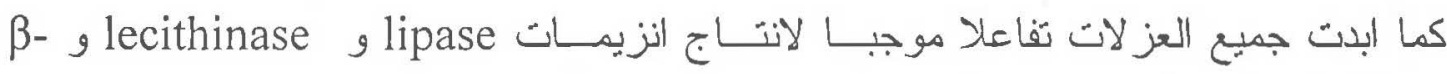
.lactamase كما تم التحري عن بعض عوامل الامر اضية للجرثومة كقدرتها على الالنصاق على

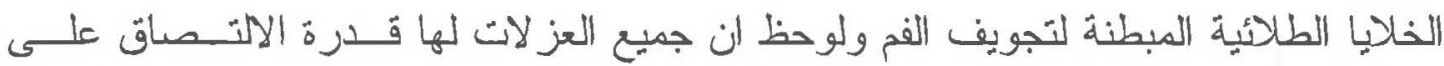

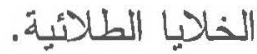

شملت الدراسة ايضا استخلاص وتحليل منعدد السكريات الدهني باعنماد تقنية الهجرة الكهربائية SDS-PAGE واظهرت النتائج وجود تباين في عدد الحزم و اوزانها الجزيئية بين

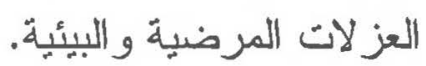

- Presented at the first conference on Biology, University of Mosul ,college of Education, 4-5 September 2007 


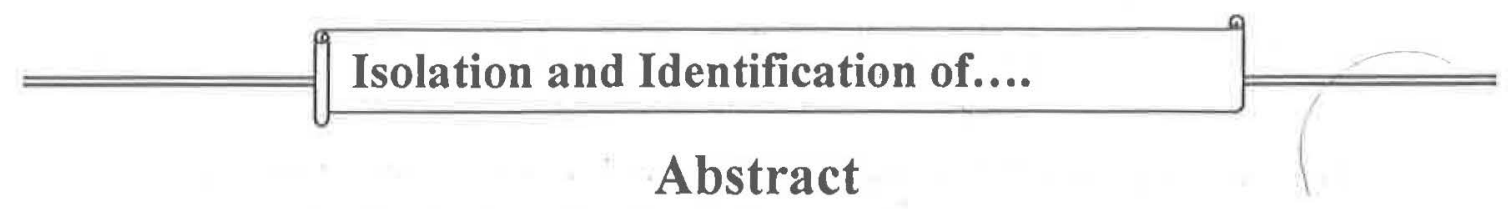

This study includes the isolation and identification of Legionella pneumophila from patient's sputum in different ages for both sexes in Komary and Rizgary Teaching Hospital in Erbil city, in addition to aquatic samples from different sources, (652) samples were collected, specimens from patients sputum, (100) water samples from bathroom tap and shower heads and other (72) water samples from cooling devices. From the patients sputum samples, $(20)$ isolates with percentage $(8.3 \%)$ were obtained, while (19) isolates (19\%) from bathroom tap and shower heads and (11) isolates (15.27\%) from cooling devices were isolated.

All isolates were identified depending on morphological, cultural, and biochemical characteristics. Depending on the results of some enzymatic activities such as protease, DNase, and starch hydrolysis enzymes, all isolates typed to eight biotypes and most of isolates were located in biotype $I$. Also all isolates were gave positive reactions for production of lipase, lecithinase, and $\beta$-lactamase.

The present study also involves the investigation of its ability to adhere to the epithelial cells of buccal cavity, and it was observed that all of the isolates have the ability to adhere to the epithelial cells.

The study also included the extraction and analysis of lipopolysaccharide (LPS) by using SDS -PAGE electrophoresis technique and the results showed that there were differences in the LPS bands number and molecular weights between clinical and environmental isolates.

\section{INTRODUCTION}

Acute respiratory infections (ARI) is one of the most important causes of morbidity and mortality in humans throughout most of the world (1). The genus Legionella is one of the most abundant of all aquatic bacteria, consisting of over 50 species, with more than 70 serogroups. Approximately 70 to $90 \%$ of Legionella infections are caused by Legionella pneumophila and other species are responsible for between 5 to $30 \%$ of the cases of infection (2).

Since Legionella pneumophila was first recognized as a disease entity from a pneumonia outbreak in July in 1976, the convention of the American Legion in Philadelphia was struck down with a mysterious acute respiratory illness (3). Investigation of the outbreak by Joseph McDad, in Centers for Disease Control and Preventation (CDC), led to the eventual discovery of the causative agent in January of 1977(7). The bacterium was subsequently named Legionella pneumophila and the disease termed legionellosis which is a disease has two distinct forms legionnaires disease and Pontiac fever (4). This bacterium belongs to the family Legionellaceae, it is faintly stained gram negative rods, 
uncapsulated, non-spore forming, with dimension from $(0.3-0.9) \mu \mathrm{m}$ in width and (2-20) $\mu \mathrm{m}$ in length, most exhibit motility by one or more polar or lateral flagella, and its cell wall contains lipopolysaccharide (LPS), which is unique from other gram negative bacteria in that its lipid consists of significant amounts of long branched-chain cellular fatty acid (5).

The primary isolation of Legionella pneumophila in laboratory is difficult, because it is fastidious and slow growing as well as it requires prolonged incubation period (3 - 10) days; therefore, culture on Buffered Charcoal Yeast Extract Agar (BCYE) plates was considered the gold standard for the laboratory diagnosis of the bacterium (6).

\section{Materials and Methods}

\section{Collection of samples:}

A total of 412 samples were collected within four

months(November 2005 to March 2006) from different sources:-

- (240) sputum specimens were taken from patients in Komary and Rizgary Teaching Hospital in Erbil city, comprising 144 (60\%) with an age ranged between 5-75 years old. The specimens collected at first morning in a sterile cup and transferred directly to the laboratory for microbiological examination.

-(172) water samples from different water sources were taken; 100 water samples from the bathroom tap and shower heads in different private homes and 72 other water samples from cooling devices in different places were taken. The water samples were collected in sterile bottles and immediately brought to the laboratory and subjected directly to microbiological examination.

\section{Culture media for isolation of $L$. pneumophila:-}

Various culture media were used to isolate this pathogen and all of these media were supplemented with iron salts and $\mathrm{L}$-cysteine $\mathrm{HCl}$ as a growth factors, also all culture media were modified by using ferric nitrate in place of ferric pyrophosphate as a source of iron in concentration $0.25 \mathrm{~g} / \mathrm{L}(6)$.

1- Buffered Charcoal Yeast Extract Agar Medium(BCYE): prepared as described by (6):

2- Feeley Gorman Agar Medium (FG): prepared as described earlier (7).

The amino acid tyrosine $(0.4 \mathrm{~g} / \mathrm{L})$ was added to enhance the growth of Legionella.

3- Yeast Extract Tyrosine Agar Medium (YET): (8).

4-Modified Wadowsky Yee Medium (MWY): (9).

After the samples were transferred directly to the laboratory, the (sputum) was inoculated by sterilize swabs in all above media while, 
water samples were pretreated with an $\mathrm{HCl}-\mathrm{KCl}$ buffer mixture at $\mathrm{PH} 2.2$ for 3-5 minutes and then inoculated by transferring $0.1 \mathrm{ml}$ of each sample in the same above media and spread with $\mathrm{L}$-shaped rod, then incubated at $37^{\circ} \mathrm{C}$ for 3-10 days in $2.5-5 \% \mathrm{CO}_{2}$ by using candle jar (6).

Morphological test, Microscopic examination and Biochemical tests wer doen according to $5,6,10,11$.

\section{Biotyping}

All isolates of $\boldsymbol{L}$. neumophila were biotyped depending on the different results of some enzymatic reactions such as protease, DNase, and starch hydrolysis enzymes which have role in occurance of infection.

\section{Adherence assay}

The adherence assay by using Geimsa stain was conducted to emphasize the pathogenesis of $L$. pneumophila. According to $12,13,14$.

\section{Extraction and purification of lipopolysaccharid (LPS)}

The LPS from $L$. pneumophila was isolated depending on (15).

\section{Results and Discussion:}

A total of 412 samples were collected from different sources; 20 (8.33\%) isolates of $\boldsymbol{L}$. pneumophila were isolated from 240 sputum samples. This result were in agreement with that reported by (16), who demonstrated a total of 74 sputum samples $7(9.5 \%)$ specimens yielded L. preumophila. This percentage is relatively low and this may be due to that the isolation of Legionella from sputum is more difficult because of the predominance of bacteria of other normal flora (5).

On the other hand, our results showed that the incidence of the infection was more common in elderly men than others and these results were in accordance with that reported by (16).

Moreover, 19 (19\%) isolates of $\boldsymbol{L}$. pneumophila were isolated from 100 samples of the bathroom tap and shower and these results were similar to that obtained by (17) but lower than other pervious studies. $14,15,16$.

The first evidence of the association between potable water from shower and nosocomial legionellosis was reported approximately 20 years ago (18). On account of its tolerance to heat and low nutritional needs $\boldsymbol{L}$. pneumophila is widespread in many water systems and the hot water system is thought to be the most frequent source of cases $(16,18)$. In many outbreaks hot water systems are the most frequently involved sources of infection $(16,18)$ and it may be due to water temperature, presence of sediment and metals content, type and age of tank and distribution system in addition to uncontinuously cleaning of bath room. 
Concerning water samples of 72 cooling device samples, $11(15.27 \%)$ samples yielded $\boldsymbol{L}$. pneumophila isolates as appear in and these results were similar to those reported by (17); this percentage was not higher than that results obtained by $(19,20)$ which they isolated $60 \%$, and $93.7 \%$ respectively of $L$. pneumophila in their studies.

A number of laboratory prepared media were used. The results showed that selective media have the best efficiency for isolation and growth of $\boldsymbol{L}$. pneumophila. On BCYE Iridescence grayish-white colonies with cut-glass appeared on BCYE agar after 7 days of incubation at $37^{\circ} \mathrm{C}$ and $2.5-5 \% \mathrm{CO}_{2}$ (fig. 1) and these results were in accordance with $(6,21)$. This medium is an excellent selective medium for $L$. pneumophila because it was supplemented with amino acid L-cystein and ferric nitrate as source of iron that provides energy and carbon and enhances the growth of bacteria (8). In addition to $\alpha$-Ketoglutarate and activated charcoal which support Legionella growth by reducing production of hydrogen peroxide (22). Also this medium is supplemented with yeast extract as a source of nitrogen (8).

On FG agar medium small browning colonies was appeared (fig. 2 ), because the medium contain of amino acid tyrosine which stimulated the growth of Legionella.

Brown colonies of $\boldsymbol{L}$. pneumophila were detected after an incubation period at $37^{\circ} \mathrm{C}$ for 7 days on YET medium as showed in fig. (3). The results of our study were in agreement with that reported by (8).

However, this medium consists of essential growth factors such as L-cystin, tyrosine and ferric nitrate in addition to yeast extract as a source of protein (19).

On MWY medium colonies green iridescence with cut-glass shape as showen in fig. (4) and these results were in accordance with that reported by (23), they mentioned that this medium was BCYE agar with antimicrobial agents such as polymyxin B (that inihibits the growth of gram negative bacteria), vancomycine (inhibits the growth of gram positive bacteria) and anisomycin (which inhibits the growth of yeast and fungi), and differential dyes such as bromothymol blue and bromocresol purple. In addition to amino acid glycin which sufficiently inhabited the non- Legionellaceae bacteria and as a result greatly facilitated the isolation of $\boldsymbol{L}$. pneumophila from specimens (9). 


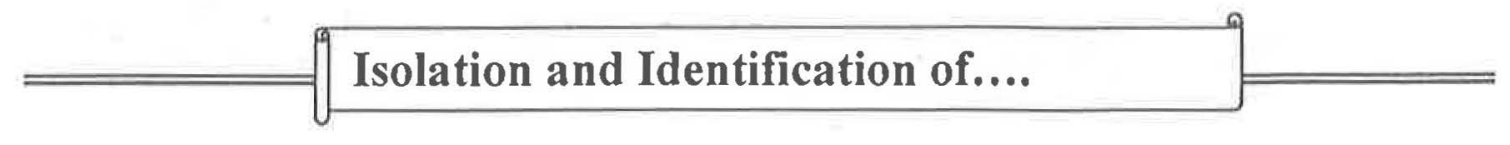

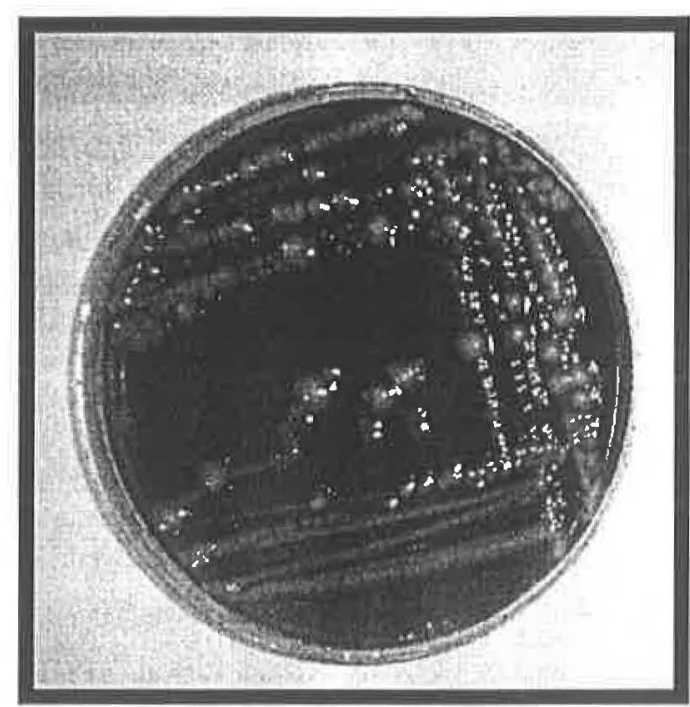

Fig . (1): Growth of $\boldsymbol{L}$. pneumophila on BCYE Agar Medium .

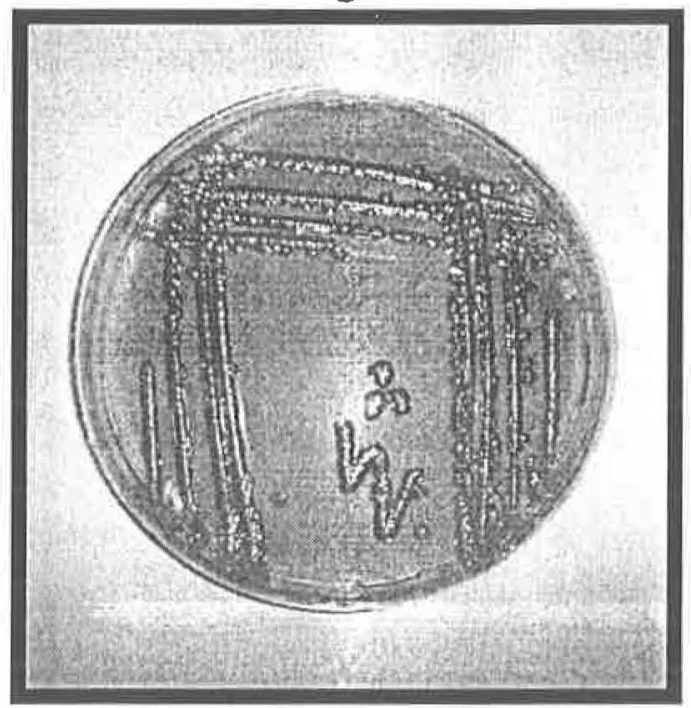

Fig. (3): Growth of L. pneumophila on Yeast Extract Tyrosine Agar Medium .

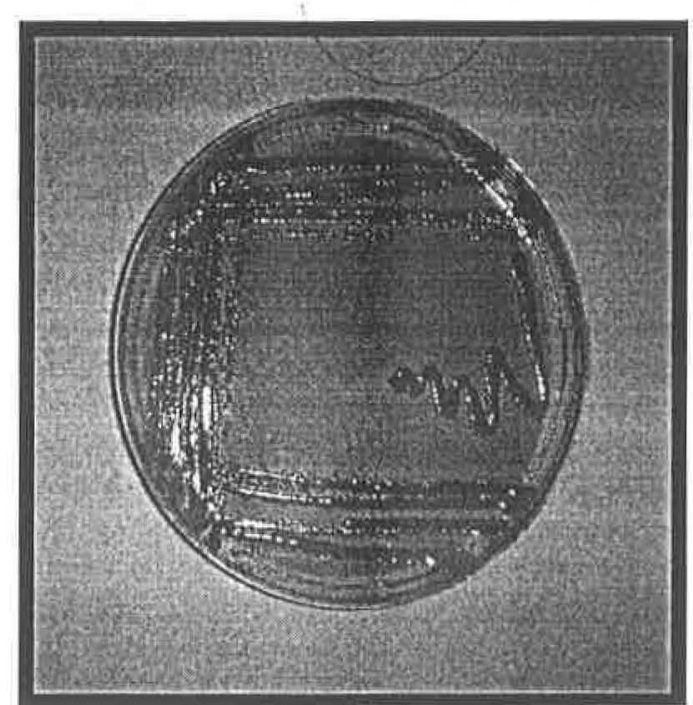

Fig. (2): Growth of $L$. pneumophila on Feeley Gorman Agar Medium.

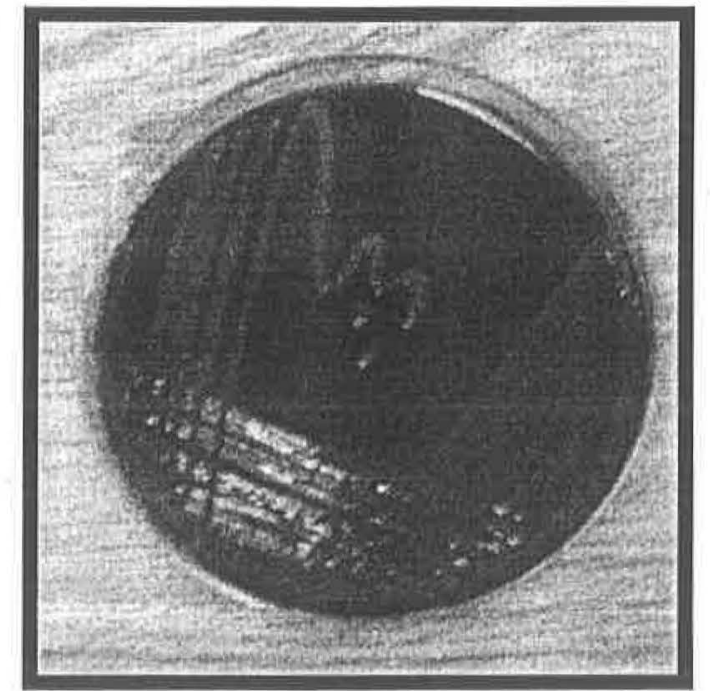

Fig. (4): Growth of L. pneumophila on MWY Agar Medium.

Each isolate was examined by Gram staining and the results of this study showed that this bacterium was non-spore forming, non capsulated, and poorly-stained gram negative rods (fig. 5). These results were agreed with that published by (21) .

Legionella is weakly stained with gram stains as it is revealed by (7), because of that Geimsa stain used in this study. In this case the bacteria were stained by blue-purple color (fig.6) and these results were in accordance with those reported by $(5,10)$.

Also when smears of Legionella were stained with Acridine orange, it appeared as iridescence orange, small rods when examined 
under fluorescent microscope (fig.7) and those results were in agreement with (17).
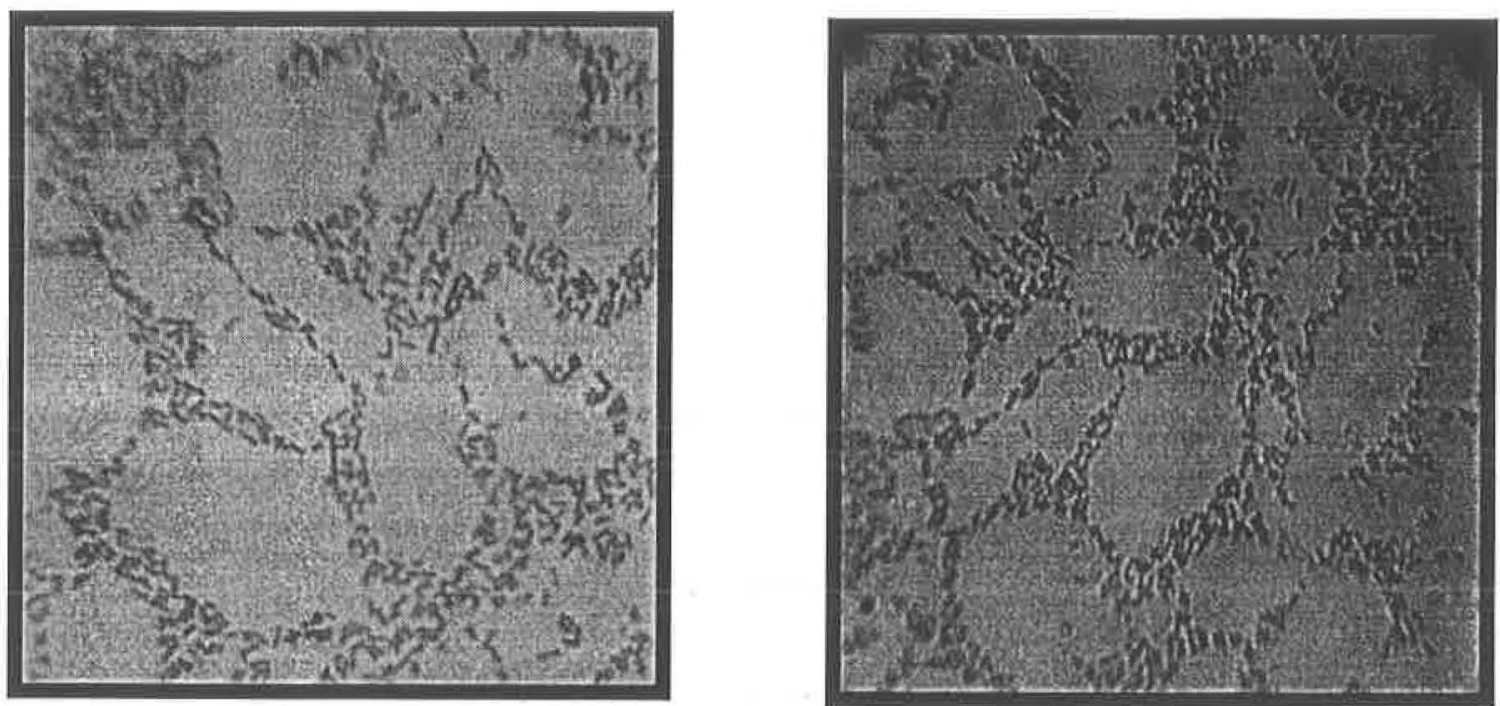

Fig. (5): L. pneumophila cells stained Fig. (6): L. pneumophila cells stained with Gram stain (1000X). with Geimsa stain (1000X).

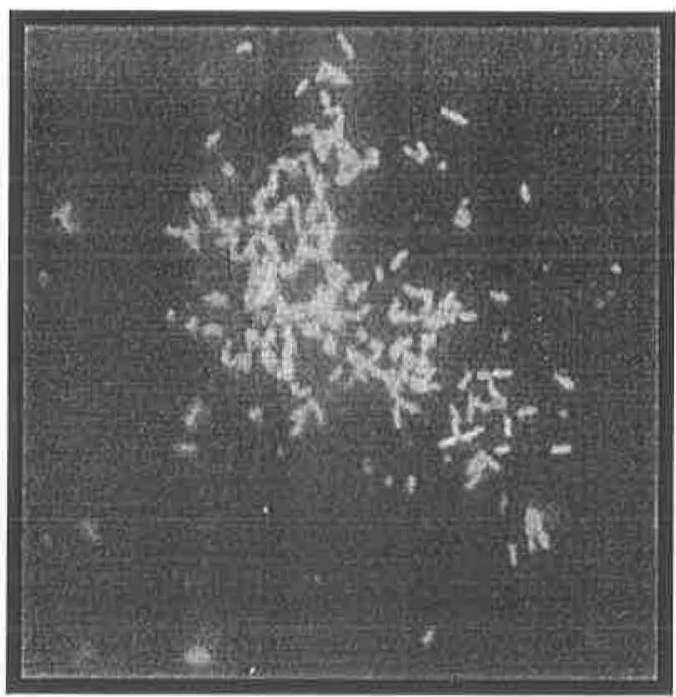

Fig. (7): L. pneumophila cells stained with Acridine Orange stain (1000X). 


\section{Biochemical tests}

Table 1 shows the biochemical characteristics of $L$. pneumophila isolated from clinical and environmental samples:

Table 1: Results of biochemical tests for $L$. pneumophila bacteria under study.

\begin{tabular}{||c|c|c||}
\hline Biochemical tests & $\begin{array}{c}\text { Results of clinical } \\
\text { isolates }\end{array}$ & $\begin{array}{c}\text { Results of environmental } \\
\text { isolates }\end{array}$ \\
\hline Oxidase test & $+(100 \%)$ & $+(100 \%)$ \\
\hline Catalase test & $+(100 \%)$ & $+(100 \%)$ \\
\hline Gelatinase test & $+(100 \%)$ & $+(100 \%)$ \\
\hline Hippurate hydrolysis test & $+(100 \%)$ & $+(100 \%)$ \\
\hline Starch hydrolysis & $+(85 \%)$ & $+(80 \%)$ \\
\hline DNase test & $+(95 \%)$ & $+(83.33 \%)$ \\
\hline Lipase and Lecithinase test & $+(100 \%)$ & $+(100 \%)$ \\
\hline Protease test & $+(95 \%)$ & $+(90 \%)$ \\
\hline Urease test & - & - \\
\hline Nitrate reductase & - & $+(100 \%)$ \\
\hline Motility test & $+(100 \%)$ & \\
\hline IMViC test & - & \\
\hline
\end{tabular}

(+): Positive

(-): Negative

\section{Biotyping of L. pneumophila:-}

From table 2 it was found that a total of 50 clinical and environmental isolates, $33(66 \%)$ of isolates were located in biotype I depending on their ability to produce protease, DNase, and starch hydrolysis enzyme.

While, 7 isolates in percentage (14\%) were located in biotype II which produce protease and DNase enzyme. However, 5 isolates which represent (10\%), were located in biotype III that gave positive response to protease and starch hydrolysis test. On the other hand, only one environmental isolate $(2 \%)$ was located in biotype VI because this isolate has the ability to produce only protease enzyme. Whereas, 3 isolates with percentage $(6 \%)$ were located in biotype $\mathrm{V}$ depending on their ability to produce DNase and starch hydrolysis enzyme. In addition, only one isolate of environmental isolates was located in biotype IV which was able to produce only DNase enzyme and gave a negative reactions to other two tests. In this study there is no isolate located in biotype IIV and IIIV. 
Our results indicated that all isolates were distributed in six biotypes and most of them were located in biotype I because most of $L$. pneumophila isolates have the ability to produce these enzymes counted as virulence factor and have role in occurrence of infection.

Table 2: Biotyping of $L$. pneumophila isolates.

\begin{tabular}{|c|c|c|c|c|c|c|c|c|}
\hline \multirow{2}{*}{ Test System } & \multicolumn{8}{|c|}{ Biotypes } \\
\hline & I & II & III & VI & V & IV & IIV & IIIV \\
\hline Protease & + & + & + & + & - & - & - & - \\
\hline DNase & + & + & - & - & + & + & - & - \\
\hline $\begin{array}{c}\text { Starch } \\
\text { Hydrolysis }\end{array}$ & + & - & + & - & + & - & + & - \\
\hline $\begin{array}{l}\text { No. of clinical } \\
\text { isolates }(\%)\end{array}$ & $\begin{array}{c}15 \\
75 \%\end{array}$ & $\begin{array}{c}3 \\
15 \% \\
\end{array}$ & $15 \%$ & & $15 \%$ & & & \\
\hline $\begin{array}{c}\text { No. of } \\
\text { environmental } \\
\text { isolates }(\%)\end{array}$ & $\begin{array}{c}18 \\
60 \%\end{array}$ & $\begin{array}{c}4 \\
13.33 \\
\% \\
\end{array}$ & $\begin{array}{c}4 \\
13.33 \\
\%\end{array}$ & $\begin{array}{c}1 \\
3.33 \%\end{array}$ & $\begin{array}{c}2 \\
6.67 \%\end{array}$ & $\begin{array}{c}1 \\
1.33 \%\end{array}$ & & \\
\hline Total & $\begin{array}{c}33 \\
66 \%\end{array}$ & $714 \%$ & $\begin{array}{c}5 \\
10 \%\end{array}$ & $12 \%$ & $36 \%$ & $12 \%$ & & \\
\hline
\end{tabular}

$(+)$ : Positive

$(-)$ : Negative

Adherence assay:-

Our finding indicated that all isolates of $L$. pneumophila have the ability to adhere to the epithelial cells of the human buccal cavity as it appears in fig. (8) and these results were in agreement with that published by (24).

L. pneumophila is a facultatively intracellular pathogen that is able to adhere, infect, multiply within, and kill human macrophages as well as free-living amoeba (24). The ability of $\boldsymbol{L}$. pneumophila to grow within mammalian cells, such as monocytes and alveolar macrophages, is essential for Pathogenicity in humans.

Furthermore, (25) demonstrated that interaction between intracellular pathogens and host cells are mediated through attachment of a bacterial ligand, such as a pilus, to a receptor on the surface of a host. 


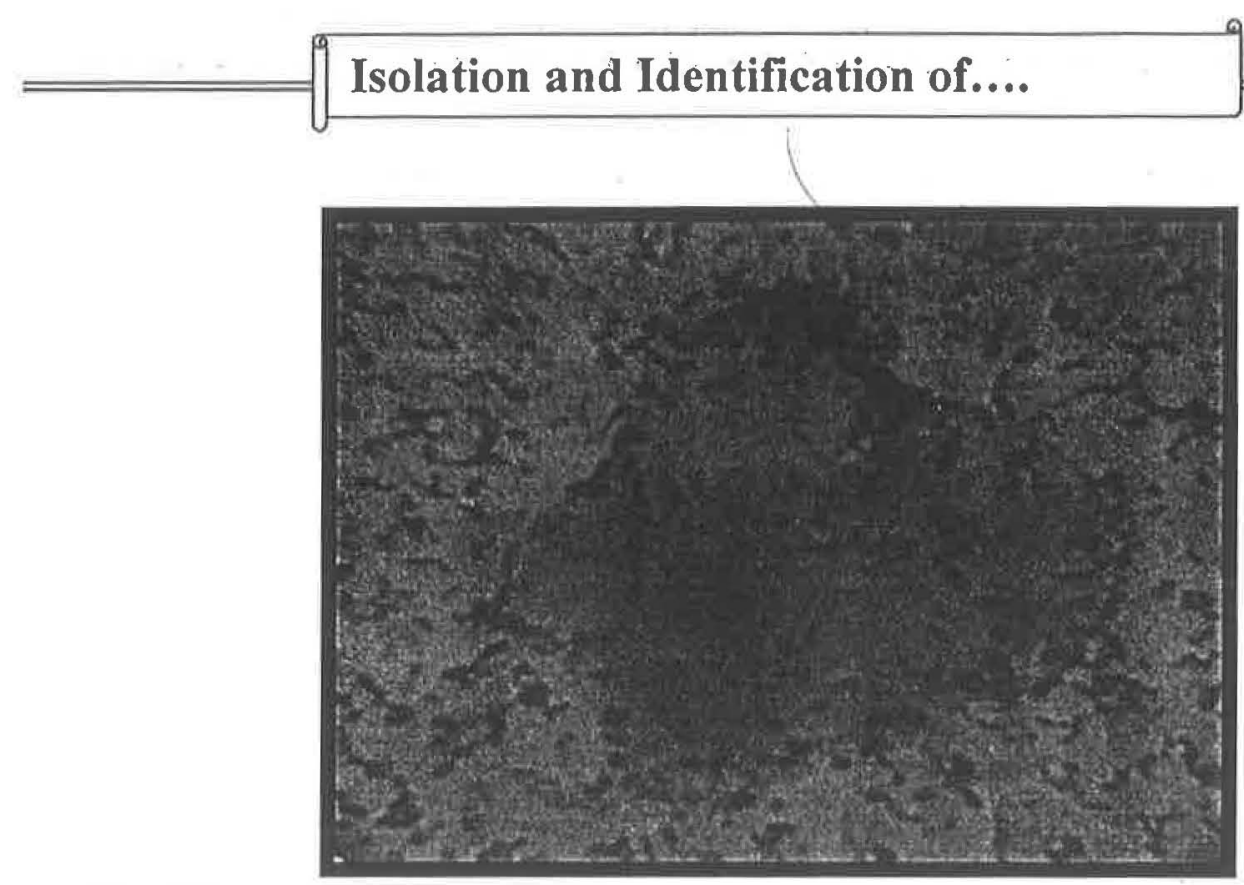

Fig. (8): Adherence of $L$. pneumophila to the epithelial cells of the human buccal cavity (1000X).

On the other hand, many researchers reported that $L$. pneumophila had a high ability to adhere to the host cells by specific receptors presented on the surface of the host cells and these receptors were proteins which differ from host to another $(25,26)$.

\section{Separation of LPS by using SDS-PAGE Electrophoresis:-}

The LPS of clinical (lane B) and environmental (lane C) isolates of L. pneumophila were analyzed by SDS-polyacrylamide gel electrophoresis and the results of our study showed differences in the number and molecular weights of bands which were estimated depending on standard curve of standard proteins as it illustrated in table 3 and fig. (9).

Table 3: The relationship between molecular weight and relative distance of standard proteins for determining the approximate molecular weight of LPS using SDS-PAGE technique.

\begin{tabular}{||c|c|c|c||}
\hline \multirow{2}{*}{ Standard Proteins } & \multicolumn{2}{|c|}{ Molecular weight } & $\begin{array}{c}\text { Relative distance } \\
\text { (cm) }\end{array}$ \\
\cline { 2 - 3 } & Kilo Dalton & Logarithm & 0.1 \\
\hline$\Gamma$-Globulin & 150 & 5.1 & 0.3 \\
\hline Transferine & 80 & 4.9 & 0.6 \\
\hline Pepsin & 67 & 4.8 & 0.8 \\
\hline Trypsin & 20 & 4.3 & 0.9 \\
\hline Lysozyme & 14 & 4.1 & \\
\hline \hline
\end{tabular}




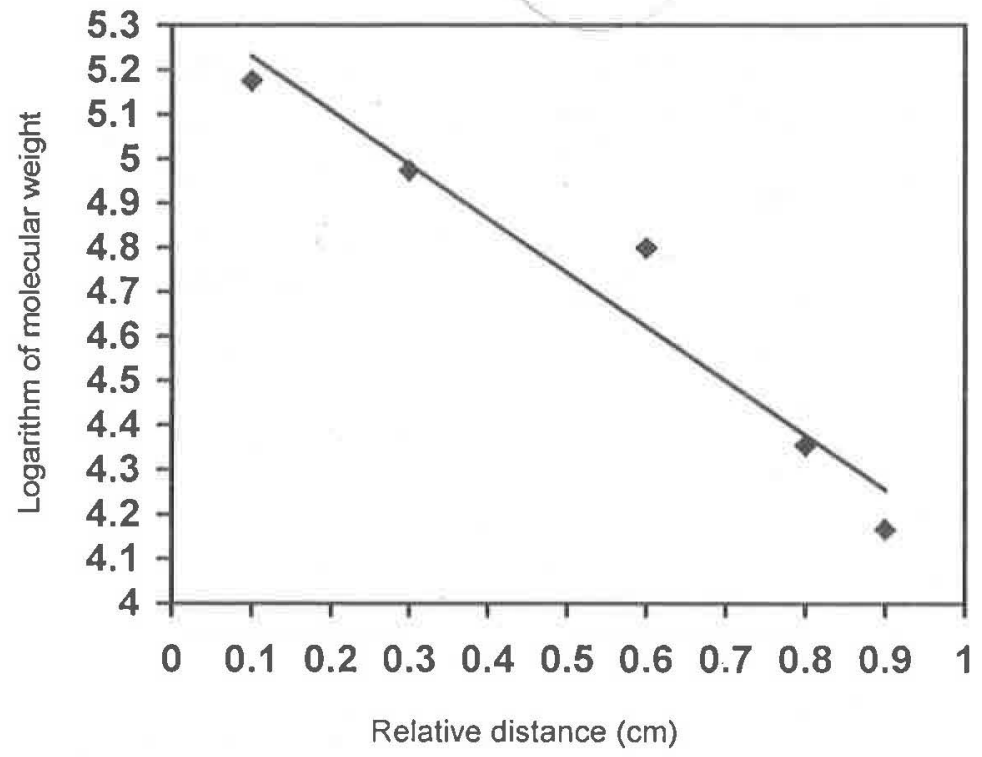

Fig. (9): Standard curves for determination of the molecular weight using SDS-PAGE technique.

From fig. (10) we found that the representative LPS profile of L. pneumophila (lane B) gave four bands with different molecular weight ranged (20 - 138) KD, whereas, the LPS of $\boldsymbol{L}$. pneumophila (lane C) gave seven bands representing different molecular weights ranged from (27 144) KD and this results were similar to that obtained by (27) when they revealed that the migration characteristics of LPS from $L$. pneumophila strains were very distinctive .

Moreover,(27) demonstrated that the individual differences in the LPS banding patterns after SDS -PAGE were due to the different numbers of representing units in the O-site chain of the LPS molecule and it has been suggested that exhibited different LPS profiles in SDS -PAGE are likely to possess serologically distinct $\mathrm{O}$-antigens .

Furthermore, LPS of $L$. pneumophila is considered a factor mediating pathogenicity. It is the major immunodominant antigen and represents the basis for the classification of serogroups $(28,29)$. In contrast to enterobacterial LPS activation it has been shown that Legionella LPS is able to activate both classical and alternative complement pathway (28). Due to the exceptional chemical structure of the $L$. pneumophila LPS, it is likely that the molecule participates in a number of essential Legionellae capabilities, such as adaptation to various environmental challenges (29). 


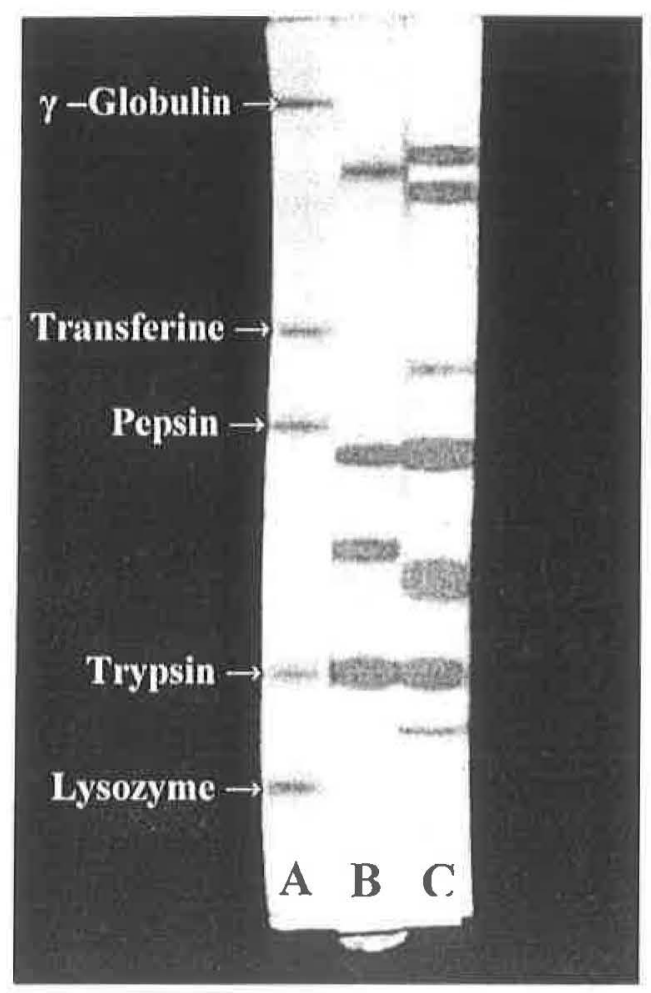

Fig. (10): Separated protein and LPS bands by using SDS-PAGE technique :

Lane (A): Standard proteins bands.

Lane (B): Clinical isolate bands.

Lane (C): Environmental isolate bands.

However, (30) revealed that the Legionella strains showed large number of broader bands, representing different molecular weights ranged from (14-95)KD and also they typed (430) strains of $\boldsymbol{L}$. pneumophila to different serogroupe depending on LPS profile SDS PAGE and silver staining. by using. 


\section{References}

1- Walter, E.B.Jr and Shurin P.A.. "Acute respiratory infections". In: Krugman S.,Katz SL,Gershon AA,Wilfert CM,eds.Infectious Diseases of Children. St.Louis, Mo: Mosby-year Book: 329-375. (1992)

2- Edelstein, P. H. and Meyer, R. D. J. E. Pennington. Respiratory Infections Raven Press, Ltd., New York, N. Y.: 455-484. (1994)

3- Englis, T.J. Legionellosis: Lecture notes Bsc. Pathcentre. 86: 33-41. (1994)

4- Sabria ,M. and Victor L. J. Clin. Microbiol,11:554-562. (2002)

5- Jawetz, E.; Melnick, J. L.; Adelberg, E. A.; Brook, G. F.; Butel, J. S. and Morse, S. A. "Medical Microbiology". 22nd ed., Appleton and Lange. New York. (2001)

6- Koneman, E. W.; Allen, S. D.; Janda, W. M.; Screchenberger, D.C. and Winn, W. C. "Color Atlas and Textbook of Diagnostic Microbiology ". 5th ed., Lippicott -Raven Published, Philadelphiia, USA. pp: 369-489. (1997)

7- Feeley, J. C.; Gorman, G. W.; Weaver, R. E.; Mackel, D. C. and Smith, H. W. J. Clin. Microbiology. 8(3): 320-325. (1978)

8- Harrison, T. G. and Taylor, A. G. "A laboratory Manual for Legionella". Wiley, New York, USA. (1988)

9- Wadowsky, R. M. and Yee, R. B. J. Clin. Microbiol. 42: 768-772. (1981)

10- Behrman, R. E.; Kliegman, R. M. and Jenson, H. B. "Nelson textbook of Pediatrics". 17th ed., Saunders. An Imprint of Elsevier Science .pp:443. (2004)

11- Mac Carthy, L.R. and Senne, J.E. J. Clin. Microbiol. 11:281-285. (1980)

12- Ofek, L.; Courtney H. S.; Schifferli, D. M. and Beachey, E. H. J. Clin. Microbiol. 24: 512-516. (1986)

13- Cruickshank, R.; Duguid J. P.; Marmion, B. P. and Swain R. H. A. "Medical microbiology", Vol. 2. The practice of medical microbiology. 12th Ed. Churchill Living Stone, London. (1975)

14- Van Den-Bosch, j. E.; Verboon-Sohmer, U.; Postma, P.; DeGraaf, J. and Mac Laren, D. M. J. Infect. Immune. 29: 226-233. (1980)

15- Yujihaishima, H.; Seitchi, K. and Kazuhito, H. J. General Microbiol. 134: 1827-1833. (1988)

16- Kaya, D.; Erginel, S.; Metintas, M.; Ustuner, Z.; Ucgun, I. and Ozdemir, N. Turk. J. of Med. Sci. 31: 73-77. (2001)

17- Al-Allaf, M. A. MSc. Isolation and Identefecation of L.pneumophila from deferent sources in Mosul sity Thesis. Mosul University. Iraq. (2005)

18- Tobin, J. O.; Beare, J.; Dunnill, M. S.; Fisher-Hoch, S.; French, M. and Mitchell, R. G. J. of Lanc. 2: 118-121. (1980)

19- Hadgson, J. M. and Casey, B. J. New York. 10: 68-75. (1998) 
20- Wahala, W. M. Ceylon J. of Med. 45: 4-10. (2000)

21 - Forbes, A. B.; Sahm, D. F. and Weissfeld, A. S. "Bailey and scott's Diagnostic Microbiology". 9th ed., Mosby. pp: 486. (2002)

22- Environmental Protection Agency (EPA). Washington. U.S.A. (1999)

23- Garrity, G.M.; Brown, A. and Vickers, R.M. Int. J. Syst. Bacteriol. 30: 609-614. (1980)

24- Cirillo, S. L. G.; Lum, J. and Cirillo, J. D. J. Infect. Immune. 62: 3427-3434. (2000)

25- Stone, B. J. and Abu-Kwaik, Y. A. J. Bscteriol. 181: 1395-1402. (1999)

26- Venkataraman, C.; Haack, B. J.; Bondada, S. and Abu Kwaik, Y. J. Exp. Med. 186: 537-547. (1997)

27- Palva, T. and Makela, P. M. J. of Eur. Biochem. 107: 137-143. (1980)

28- Rechnitzer, C. J.APMIS Suppl. 43: 1-43. (1994)

29- Luneberg, E.; Zahringer, U.; Knirel, Y. A.; Steinmann, D.; Hartmann, M.; Steinmetz, I.; Rohde, M.; Kohl, J. and Frosch, M. J. Exp. Med., 188(1): 49-60. (1998)

30- Jurgens, D. and Fehernback, F. J. J. Clin. Microbiol. 35(12): 30543057. (1997) 